\title{
Distribution Channel Analysis of Logistics in Supply Chain Management at the Outlet IAP With VSM in Agricultural Sector Industrial Companies
}

\author{
Bethriza Hanum \\ Department of Industrial Engineering, Universitas Mercu Buana \\ DKI Jakarta, Indonesia
}

Corresponding author details: Bethriza Hanum

\begin{abstract}
PT. PP London Sumatra Indonesia Tbk is a company engaged in agribusiness, which tried to become a retail company in 2016 with Kahuripan Tea products, namely teabags processed from their factories and gardens in the Bandung, West Java area. With marketing areas in West Java and East Java, the focused area is the Jabodetabek area in this research. The problem faced by the company is the delay in the transport order process, which results in delays in the delivery of Kahuripan Tea products to customers. The data on delays used are data from October to December 2019. The problem occurs because there are still many activities that are not value-added which are classified as waste. This research aims to analyze improvements in the transport order process that occurs in the business development and procurement department at PT. PP London Sumatra Indonesia Tbk, with a lean manufacturing approach with the value stream mapping (VSM) method, analyzes the dominant waste in the transport ordering process. Based on the analysis results, there were three improvements, namely the approval process, the price bidding process, and the vendor selection process. The results of the improvement evaluation obtained a decrease in lead time by 560 minutes and an increase in the value of Process Cycle Efficiency by $46 \%$. So, this improvement will increase the practical value in the transport ordering process: that way, PT. PP London Sumatra Indonesia Tbk can increase customer value with fast service time and good quality.
\end{abstract}

Keywords: lean manufacturing; value stream mapping; waste; efficiency

\section{INTRODUCTION}

Logistics in its development until now has become a science that must be paid special attention to considering the increasingly complex history of economic growth such as the productivity of goods produced by factories or companies, how to distribute and store them, and to manage product products as a whole require special and severe handling. To achieve efficient results and all effectiveness requires a good organization or is often termed integrated logistics management so that there is no imbalance in carrying out its activities.

PT PP London Sumatra Indonesia Tbk, as a company engaged in the agribusiness sector, continues to innovate its products, especially in improving the product delivery process to help and support sales; one of its main products is Kahuripan Tea. Currently, Kahuripan Tea has spread in several Indonesian provinces, such as West Java and East Java. As a form of logistics role in trading companies, which generally still have limitations in the application and logistics system, the company is faced with various forms of threats both internally and externally. Especially in network logistics distribution, there are significant subproblems that the company must solve and make logistics an appropriate technology. For this reason, it is necessary to implement well-planned and well-organized logistics management.
The problem faced by PT PP London Sumatra Indonesia Tbk in product distribution was the delay in the product to Indomarco Adi Prima (IAP) outlets. Delay in delivery can be seen in table 1

TABLE 1: Table of Problems Delivery of Tea to IAP Stores

\begin{tabular}{|l|l|}
\hline RO IAP & \multicolumn{1}{|c|}{ ISSUE } \\
\hline \multirow{5}{*}{ Jakarta } & $\begin{array}{l}\text { 1. Production delays can be up to 1-2 days } \\
\text { 2. The process of ordering the old external } \\
\text { transport }\end{array}$ \\
\cline { 2 - 3 } & $\begin{array}{l}\text { 3. Transportation congestion due to the } \\
\text { direction of Jakarta }\end{array}$ \\
\cline { 2 - 3 } Bogor & 4. Transportation jam conditions \\
\hline \multirow{5}{*}{ Depok } & $\begin{array}{l}\text { 1. Production delays can be up to 1-2 days } \\
\text { 2. The process of ordering the old external } \\
\text { transport }\end{array}$ \\
\cline { 2 - 3 } & $\begin{array}{l}\text { 3. The condition is jammed because it is in } \\
\text { the middle of the city of Bogor }\end{array}$ \\
\cline { 2 - 3 } & 4. Road conditions are being repaired \\
\hline & $\begin{array}{l}\text { 1. Production delays can be up to 1-2 days } \\
\text { 2. The process of ordering the old external } \\
\text { transport }\end{array}$ \\
\cline { 2 - 2 } distribution center \\
\cline { 2 - 3 } & 4. Transportation traffic jams \\
\cline { 2 - 3 } & $\begin{array}{l}\text { 5. The condition is jammed because it is in } \\
\text { the middle of the city center }\end{array}$ \\
\hline
\end{tabular}




\begin{tabular}{|c|c|}
\hline RO IAP & ISSUE \\
\hline \multirow{3}{*}{$\begin{array}{l}\text { Tanggerang } \\
\text { Bekasi }\end{array}$} & 1. Production delays can be up to $1-2$ days \\
\hline & $\begin{array}{l}\text { 2. The location is quite far from the } \\
\text { distribution center }\end{array}$ \\
\hline & 3. Transportation current congestion \\
\hline \multirow{4}{*}{ Bekasi } & 1. Production delays can be up to $1-3$ days \\
\hline & $\begin{array}{l}\text { 2. The process of ordering the old external } \\
\text { transport }\end{array}$ \\
\hline & $\begin{array}{l}\text { 3. The condition is jammed due to } \\
\text { damaged roads }\end{array}$ \\
\hline & $\begin{array}{l}\text { 4. The condition is jammed because it is in } \\
\text { a congested area }\end{array}$ \\
\hline
\end{tabular}

From the data on the above delivery problems, such as delays in product delivery due to the distance traveled, the process for ordering external transport is quite long, transportation conditions are right roads and other conditions. It is often the main problem for most companies in managing the supply of goods to IAP outlets. As a form of the role of logistics distribution in trading companies, which generally still have limitations in the application and distribution system of logistics, companies are faced with various forms of threats, both internal and external.

The problem discussed in this study is the delay in the distribution center in supplying products to IAP outlets. Many orders from IAP and transportation are problems that are often faced. Because these problems are dynamic, so to minimize these problems requires flexibility from the distribution of logistics for effective and efficient handling in dealing with any changes that occur in the field.

\section{RESEARCH METHODOLOGY}

\section{- Type of Research}

This research is research in the form of a direct survey that analyzes the relationship between the application of logistics distribution and its effect on trading companies' supply performance. The survey was carried out through observations made at PT. PP London Sumatra Indonesia Tbk to the IAP distribution center in the Greater Jakarta area has implemented logistics distribution as an appropriate technology in the company. This study's dependent variable is the logistics distribution performance with indicators, order fulfillment level, delivery according to the due date, order lead-time order fulfillment, perfect invoice number, and delivery system flexibility to meet specific customer needs and productivity.

\section{- Types of Data and Information}

Based on the formulation of the previous chapter's problem, this research is classified as quantitative research. For this study, the authors collected the following information data:

1. Primary data is data obtained or collected by researchers directly from the data source. Primary data is also known as original data or new data that is up to date. To get primary data, researchers must collect it directly.

Primary data in this study are:

1) Number of distribution center locations

2) Amount of current transportation

3) Product inventory

4) Logistics distribution performance
2. Secondary Data, namely data obtained from other existing sources. Secondary data collection is done by:

1) Interviews, namely data collection conducted by interviews, namely data collection carried out by direct communication using questions and answers.

2) Documentation, namely data collection based on company records or archives.

3) Literature, namely the theories used in the discussion of this study.

Secondary data in this study are delivery capacity, number of transports, and efficiency obtained from research reports.

3. The data used in this study are based on the type, namely:

a) Qualitative data, namely data that is not in the form of numbers, which in this study were obtained from employee job descriptions and direct interviews related to the work they were doing.

b) Quantitative data, namely data in the form of computable numbers, which in this study were obtained from measurements of product delivery to customers.

\section{- Data Collection Methods}

The data collection methods used in the preparation of this study were as follows:

\section{Literature Study}

Looking for theoretical references relevant to the cases or problems found containing data related to the topics raised in the research. This literature study is obtained from various sources in journals, books, and the internet.

\section{Observation}

Conducting direct observations on the object under study, in this case, is the performance of logistic distribution by observing direct product delivery to obtain the results of the attributes to support the analysis in research.

\section{- Processing and Data Analysis Methods}

In this study, data collection was carried out by observing the Business Development division in each workstation's logistics section. This research uses qualitative and quantitative data types obtained directly from the company concerned. The analysis was carried out with a lean manufacturing approach using SCM (Supply Chain Management) and VSM (Value Stream Mapping) methods.

\section{RESULT AND DISCUSSION}

Based on the results of calculations made by the Business Development department of PT. PP London Sumatra Indonesia Tbk, the Value Stream Mapping (VSM) method for the period October - December 2019 can be seen in Table 2 below: 
TABLE 2: Comparison of VA, NVA, and NNVA values

\begin{tabular}{|c|c|c|c|c|}
\hline \multirow{2}{*}{$\begin{array}{c}\text { Activity } \\
\text { Classification }\end{array}$} & \multicolumn{2}{|c|}{ Before } & \multicolumn{2}{c|}{ After } \\
\cline { 2 - 5 } & Minutes & Percentages & Minutes & Percentages \\
\hline VA & 255 & $17 \%$ & 255 & $46 \%$ \\
\hline NVA & 1040 & $71 \%$ & 190 & $34 \%$ \\
\hline NBVA & 175 & $12 \%$ & 115 & $20 \%$ \\
\hline Lead Time & \multicolumn{2}{|c|}{1470} & \multicolumn{2}{c|}{560} \\
\hline PCE & \multicolumn{2}{|c|}{$17 \%$} & \multicolumn{2}{c}{} \\
\hline
\end{tabular}

Based on table 2 the company made improvements by increasing the effectiveness value in the transport ordering process to deliver Kahuripan Tea products at PT. PP London Sumatra Indonesia Tbk. Before the repair, the lead time in the process is for 1,470 minutes with a process cycle efficiency (PCE) value of $17 \%$. Meanwhile, after repairing the system or the Future State Map, the lead time obtained is 560 minutes with a process cycle efficiency (PCE) value of $46 \%$.

The following is the performance that must be improved in the transport order process for the delivery of Kahuripan products:

1) In the approval process for the business development purchase order (PO), it is not necessary to print an approval request via e-mail for the approval manager process because, in the previous stage, the purchase order (PO) has been checked with the business development team, so the purchase order (PO) is checked. ) with the manager, it did not take long.

2) In the price bidding process, the procurement team should have selected three vendors that will be involved or included in the transport order process for six months; when the user issues a purchase request (PR), the procurement team will choose from the three vendors that have been provided, and the third vendors that have been provided must be by user needs and prices by company provisions so that the time required for the process does not require a long time. This will simplify the procurement process in choosing a vendor to use.

3) In the vendor selection process, it should not take a long time; if three vendors have been selected that are by the qualifications, then the selection can be made quickly; the time given before the repair is too long where for the vendor selection process it takes 240 minutes after the repair is made then it takes only 30 minutes.

4) In the approval process at the manager level, the purchase order (PO) should not need to be printed because the approval process through SAP has already been processed. At this stage, the manager should already know the details of the purchase order (PO) and the vendor used, so the approval process does not take a long time.

Based on the improvements made using the Value Stream Mapping (VSM) method, the problem of product delays occurs at PT. PP London Sumatra Indonesia Tbk is due to ineffective performance processes, so that every process that is undertaken is a waste of time. The time needed in the transport order process is 560 minutes, consisting of 225 minutes of Value-added (VA) and 190 minutes of non Value added (NVA). With a total order time of 560 minutes, the product will not experience delays with the lead time given by the customer for three days or 1,440 minutes during working time: that way, PT. PP London Sumatra Indonesia Tbk can increase customer value with fast service time and good quality.

\section{CONCLUSION}

Based on the results of data processing and data analysis related to the transport ordering process at PT. PP London Sumatra Indonesia Tbk, which has been discussed obtained several conclusions, namely:

1. Distribution channels used by PT. PP London Sumatra Indonesia Tbk uses distribution channels from Producers - Retail - Agents - Consumers; this is because the implementation in the field using this distribution channel is more profitable.

2. In the distribution channel at PT. PP London Sumatra Indonesia Tbk has a problem, namely the ineffective distribution channels used by companies related to the transport order process function that occurs in the procurement division.

3. Based on the results of data processing that has been done using the value stream mapping (VSM) method, it can be seen that the problem of delays in delivery made by PT. PP London Sumatra Indonesia Tbk occurs in the transport order process, namely in the process of determining the vendor to the approved purchase order (PO).

\section{SUGGESTION}

The suggestions for the company are as follows:

1. Research on the distribution channel process at PT. PP London Sumatra Indonesia Tbk using the value stream mapping (VSM) method can be continued for further improvement so that there are no delays in product delivery to customers.

2. PT. PP London Sumatra Indonesia Tbk is expected to pay attention to the distribution process on product shipments internally and externally.

\section{REFERENCES}

[1] Acero, R., Torralba, M., Pérez-Moya, R., \& Pozo, J. A. (2020). Order processing improvement in military logistics by Value Stream Analysis lean methodology. Procedia Manufacturing, 41, 74-81.

[2] Haekal, J., Hanum, B., \& Adi Prasetio, D. E. 2020. Analysis of Operator Body Posture Packaging Using Rapid Entire Body Assessment (REBA) Method: A Case Study of Pharmaceutical Company in Bogor, Indonesia. International Journal of Engineering Research and Advanced Technology - IJERAT (ISSN: 2454-6135), 6(7), 27-36. 
[3] Hanum, B., Haekal, J., \& Adi Prasetio, D. E. 2020. The Analysis of Implementation of Enterprise Resource Planning in the Warehouse Division of Trading and Service Companies, Indonesia. International Journal of Engineering Research and Advanced Technology IJERAT (ISSN: 2454-6135), 6(7), 37-50.

[4] Kholil, M., Haekal, J., Eko Adi Prasetio, D.., \& Sulaiman Hasan. 2020. The Lean Manufacturing Design for Improving Production Scheduling Using Product Wheel Method in Chemical Manufacturing Company, Indonesia. International Journal of Engineering Research and Advanced Technology - IJERAT (ISSN: 2454-6135), 6(8), 12-18.

[5] Haekal, J., \& Setio, H. 2017. Selection of Raw Material Suppliers Using Analytical Hierarchy Process in Food and Beverage Company, South Jakarta. ComTech: Computer, Mathematics and Engineering Applications, 8(2), 63-68.

[6] HAEKAL, J. (2018). PERANCANGAN DAN EVALUASI IMPLEMENTASI SISTEM MANAJEMEN MUTU ISO 9001: 2015 MELALUI KEPUASAN PELANGGAN DI UNIVERSITAS ISLAM AS-SYAFI'IYAH (Doctoral dissertation, Universitas Mercu Buana Jakarta).

[7] Kholil, M., Haekal, J. H, Sulaiman. 2020. Lean Manufacturing Design to Reduce Waste in Gear Production Process Using VSM and Kaizen Method Approaches (Case Study: Gear Primary Driven K56 Product). Journal of Scientific and Engineering Research. 7(8), 1-9

[8] Haekal, J., \& Prasetio, D. E. A. Planning Of Production Facilities Layouts In Home Industry With The Systematic Layout Planning Method.

[9] haekal, J., \& Setiawan, I. (2020). Comparative Analysis of Raw Materials Control Using JIT and EOQ method For Cost Efficiency of Raw Material Supply in Automotive Components Company Bekasi, Indonesia. International Journal of Engineering Research and Advanced Technology (ijerat), 6(10), 76-82. https://doi.org/10.31695/IJERAT.2020.3661

[10] Haekal, J., Hanum, B., \& Adi Prasetio, D. E. 2020 Application of Quantitative Strategic Planning Matrix (QSPM) For Determination of Alternative Strategies in Food and Beverage SMES in Bogor Indonesia. Journal of Scientific and Engineering Research. 7(7), 137-145

[11] Hanum, B., Haekal, J., \& Adi Prasetio, D. E. 2020. SPHC Material Inventory Control Analysis in Project VL01 Centralized by the EOQ Method in Automotive Company Indonesia. Journal of Scientific and Engineering Research. 7(7), 130-136

[12] Ikatrinasari, Z. F., Hasibuan, S., \& Kosasih, K. (2018, November). The implementation lean and green manufacturing through sustainable value stream mapping. In IOP Conference series: materials science and engineering (Vol. 453, No. 1, p. 012004). IOP Publishing.
[13] Bantacut, T., \& Fadhil, R. (2018). Penerapan LOGISTIK 4.0 dalam Manajemen Rantai Pasok Beras Perum BULOG: Sebuah Gagasan Awal Application of LOGISTICTS 4.0 in Rice Supply Chain Management at Perum BULOG: An Initial Idea.

[14] Bowersox, D. J. (2006). Manajemen Logistik Integrasi sistem-sistem Manajemen Distibusi Fisik dan Manajemen Material. Jakarta : Bumi Askar

[15] Djunaidi, Arikunto. (2006). Analisis Kepuasaan Pelanggan dengan Pendekatan Fuzzy Service Quality dalamk8 upaya Peningkatan Kualitas Pelayanan. Jurnal Ilmiah Teknik Insutri. Vol. 4, No.3 halaman 139-146

[16] Faisal, F. (2018). APLIKASI HASIL PENCARIAN DAN RUTE PENGIRIMAN BARANG DARI SOLUSI MASALAH TRANSPORTASI BIKRITERIA DENGAN METODE LOGIKA FUZZY. Jurnal INSTEK (Informatika Sains dan Teknologi), 2(1), 91-100.

[17] Fajrian, M. (2018). Penerapan Sistem Value Stream Mapping Untuk Peningkatan Hasil Produksi Sparepart Sepeda Motor Mainstand 2sd. Operations Excellence, 10(3), 252-262.

[18] Ghiani, G. L. (2004). Introduction to Logistic Systems Planning and Control. John Wiley : England

[19] Gaspersz, V. (2001). Total Quality Management. Edisi 1. Jakarta : PT. Gramedia Pustaka Utama

[20] Heizer, J. \& Render, B. (2006). Operations Management. Edisi 7. Jakarta : Salemba 4

[21] Kholil, M., \& Mulya, R. (2016). Minimasi Waste dan Usulan Peningkatan Efisiensi Proses Produksi Mcb (Mini Circuit Breaker) dengan Pendekatan Sistem Lean Manufacturing (di PT Schneider Electric Indonesia). Penelitian dan Aplikasi Sistem dan Teknik Industri, 8(1), 182851.

[22] Kotler, P. (2009). Manajemen Pemasaran. Edisi 9. Jakarta : PT. Prenhallindo

[23] Lupiyoadi, R. \& Hamdani, A. (2006). Manajemen Pemasaran Jasa. Edisi 2. Jakarta : Salemba Empat

[24] Momon, A., \& Ardiatma, D. W. (2018). Penentuan Rute Distribusi Suku Cadang Kendaraan Bermotor dalam Meminimalkan Biaya Transportasi (Studi Kasus: PT. Inti Polymetal Karawang). JIEMS (Journal of Industrial Engineering and Management Systems), 11(1).

[25] PT. PP London Sumatra Indonesia Tbk. (2018). Annual Report Laporan Tahunan . Jakarta : Kuningan

[26] SEMBIRING, D. (2018). Penerapan Lean Manufacturing Dengan Metode VSM (Value Sream Mapping) untuk Mengurangi Waste Pada Proses Produksi Pt. XYZ.

[27] Tannady, H. (2015). Pengendalian Kualitas. Yogyakarta : Graha Ilmu 